\title{
Channel cross-section influence on effective strain distribution in ECAP process
}

\author{
Wpływ przekroju kanału kątowego \\ na rozkład intensywności odkształcenia w procesie ECAP
}

\begin{abstract}
This study compares the numerically determined strain distributions after the application of the method of equal-channel angular pressing. The calculations were performed for four variants of the channel cross-sectional shapes - square, circular, and two rectangular ones with the same transverse surface area. The calculation results have been demonstrated as maps of effective strain distribution in the stabilized process.
\end{abstract}

Keywords: effective strain, homogeneity of strain, equal-channel angular pressing

\section{Streszczenie}

W pracy porównano wyznaczone numerycznie rozkłady odkształceń po zastosowaniu procesu przeciskania przez kanał kątowy. Obliczenia wykonano dla czterech wariantów przekroju kanału kwadratowego, kołowego i dwóch prostokątnych, o takim samym polu powierzchni poprzecznej. Wyniki obliczeń przedstawiono w postaci map rozkładu intensywności odkształcenia w procesie ustalonym.

Słowa kluczowe: intensywność odkształcenia, jednorodność odkształcenia, przeciskanie przez kanał kątowy

\section{Introduction}

SPD techniques - severe plastic deformations - are used to obtain solid metal samples with a super fine granularity of the structure that are ready for further processing. Such materials are characterized by their excellent mechanical properties, all the while

Paweł Chyła Ph.D. Eng., Sylwia Bednarek Ph.D. Eng., Aneta Łukaszek-Sołek D.Sc. Ph.D. Eng.: AGH University of Science and Technology, Faculty of Metals Engineering and Industrial Computer Science, Department of Metal Forming, Krakow, Poland; pchyla@metal.agh.edu.pl 
maintaining high ductility and crack resistance in the case of brittle materials [1]. This article analyzed the influence of the cross-sectional shape of a die channel on the strain homogeneity of material subject to Equal Channel Angular Pressing (ECAP).

The literature provides numerous equations that allow us to theoretically determine material strain in the ECAP method [2-4]. Unfortunately, they do not directly take into account the radii of the external or internal channel bends, the dimensions and crosssection of the channel, the effect of friction, or the geometry and dimensions of the shaped material. Therefore, in order to determine the effective strain in the method of equal-channel angular pressing with variable cross-sectional shapes of the channel, the authors used the numerical calculations.

\section{Design assumptions}

Figure 1 illustrates the design and dimensions of a single bend of the die channel in the analyzed ECAP method. The outer $(r 5)$ and the inner (R5) radii of the bend are equal to $5 \mathrm{~mm}$, and the angle of inclination of the die channel $\Phi$ is $90^{\circ}$. Four variants of the die channel were constructed, all of which differed in their cross-sectional shapes - the square one with a side of $26.6 \mathrm{~mm}$, the circular one with a diameter of $30 \mathrm{~mm}$, and the two rectangular ones with dimensions of $15 \mathrm{~mm} \times 47.1 \mathrm{~mm}$.

The transverse dimensions of the pressed samples corresponded to the dimensions of the channel, and the height was $100 \mathrm{~mm}$. Figure 2 illustrates the shapes of the samples obtained after the pressing as well as cross-sectional views of the channel. Their dimensions were selected so that the transverse surface area of the channel was constant for the different cross-sections.

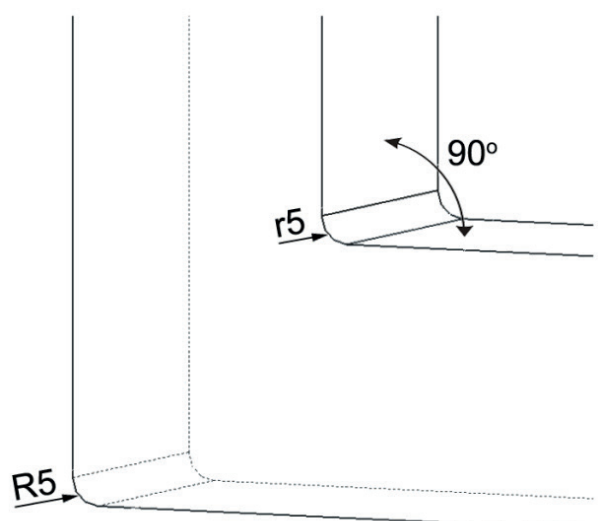

Fig. 1. Construction and basic dimensions of Channel bend in ECAP process 
a)
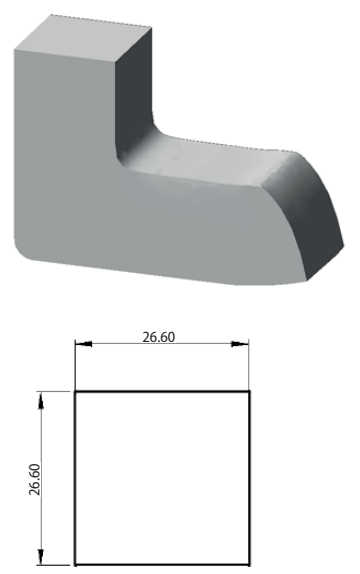

c)
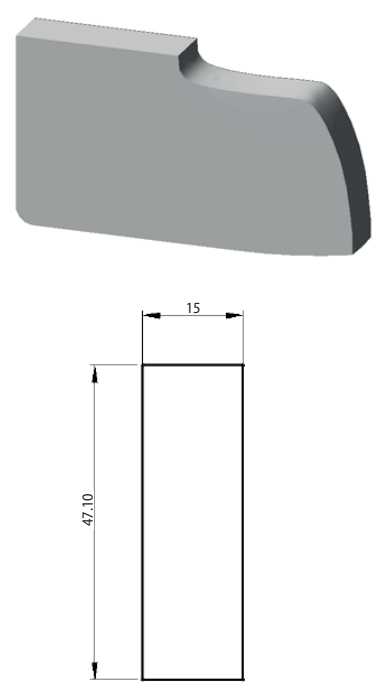

b)
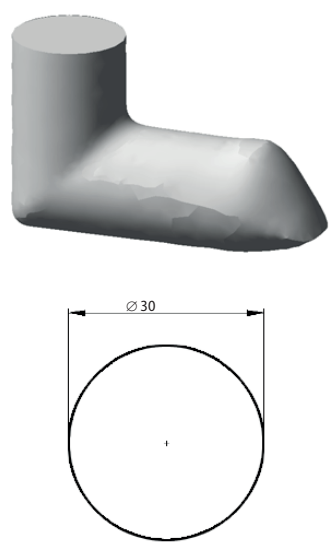

d)
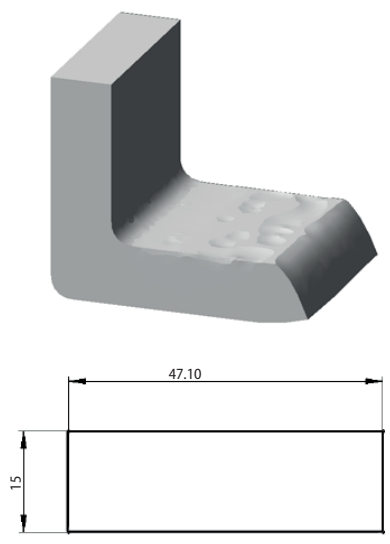

Fig. 2. Dimension of cross-section and samples shapes received after passage by channel with square section (a); circular (b); rectangular longitudinal (c); and rectangular transverse (d)

\section{Boundary conditions for numerical calculations}

Numerical calculations were performed using commercial software QForm3D based on the finite element method and on the flow plasticity theory. In order to minimize the 
effect of temperature on the obtained results, isothermal process conditions were adopted - the initial temperature of the batch and tools was predetermined at $440^{\circ} \mathrm{C}$. To avoid the effect of the material heating due to high-speed shaping, the speed of the punch was predetermined at $1 \mathrm{~mm} / \mathrm{s}$. Physicochemical properties of the deformed metal were accepted according to the data determined for aluminum alloy Al5456, with the chemical composition demonstrated in Table 1 [5] (assuming a viscoelastic model). The lubricant was a graphite-based one, with a friction coefficient of 0.27 .

Table 1. Chemical constitution of Al5456 alloy

\begin{tabular}{|c|c|c|c|c|c|c|c|c|}
\hline \multirow{2}{*}{ Determination } & \multicolumn{8}{|c|}{ Chemical constitution [\%] } \\
\cline { 2 - 10 } & Al & Cu & Si & Mn & Mg & Ti & Zn & Fe \\
\hline Al5456 & Basic & 0.04 & 0.16 & 0.63 & 6.8 & 0.1 & 0.2 & 0.22 \\
\hline
\end{tabular}

\section{Analysis of the results of numerical calculations}

In the analyzed method of equal-channel angular pressing, the cross-sectional shape of the channel is variable (which affects the value of the effective strain in the material) and, thus, determines the degree of processing and, consequently, the grain size (degree of structure granularity). The results of the numerical calculations were analyzed assuming an equal distance of the punch from the bottom of the channel; i.e., $55 \mathrm{~mm}$, for all of the variants of the equal-channel angular pressing. These are presented in Figures 3 through 7.

Figure 3 illustrates the maps of the temperature distribution in the plane of symmetry of the analyzed samples. Isothermal conditions for shaping with a low linear speed of the punch were predetermined. This allowed us to maintain an approximately constant temperature of $440^{\circ} \mathrm{C}$ throughout the entire volume of the pressed material. The local temperature rise (caused by heat deformation) ranged from $1.4^{\circ}$ to $2.7^{\circ} \mathrm{C}$ more than the value predetermined for the calculations.

Figure 4 illustrates the local effective strain distribution in the plane of symmetry and in the sections on the boundary of two adjacent channels (as shown in Figure 5). This allowed us to unambiguously compare the size of the strain in the equal-channel angular pressing, depending on the cross-sectional shape of the die channel. The maximum local values of the effective strain occur at the lower radius of the channel, and they are (respectively) 2.1-2.3 for the square and circular cross-sections (Figs. 4a and 4b), 1.35-1.45 for the longitudinal rectangular cross-section (Fig. 4c), and 1.65-1.75 for a transverse rectangular cross section (Fig. 4d). Analyzing the strain distribution maps in the plane of the channel bend, it is noticeable that the fields corresponding to the particular values of 
the effective strain are arranged in layers. The lowest values occur under the upper radius of the channel and gradually increase as they approach the lower radius. The largest gradient value of the strain in this area is for the sample pressed through the channel with the transverse rectangular cross-section - the value of the effective strain increases from 0.45 to 1.4. For other cross-sections, the minimum effective strain is from 0.35 (transverse rectangular cross-section) to 0.5 (square and circular cross-sections), and the maximum one: from 0.9 to 1.1 .

a)

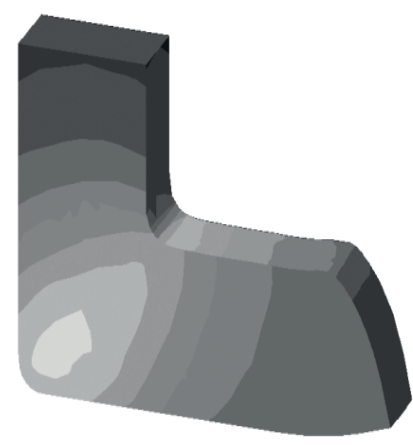

c)
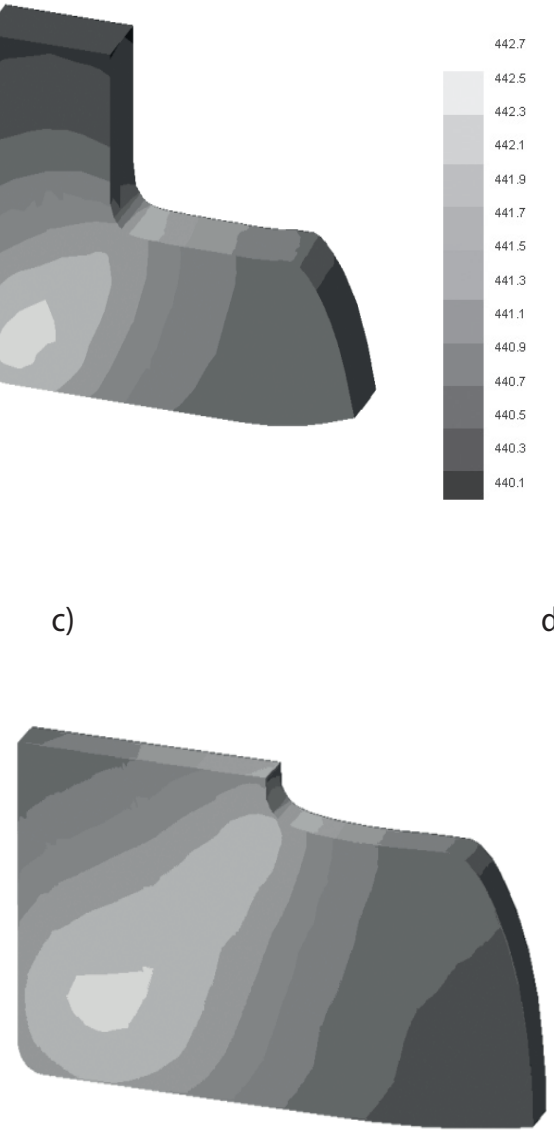

b)

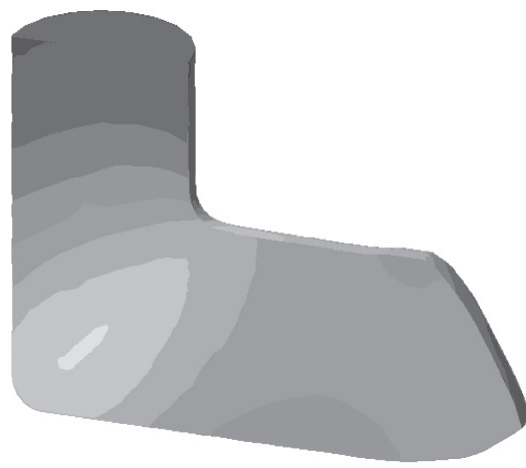

d)

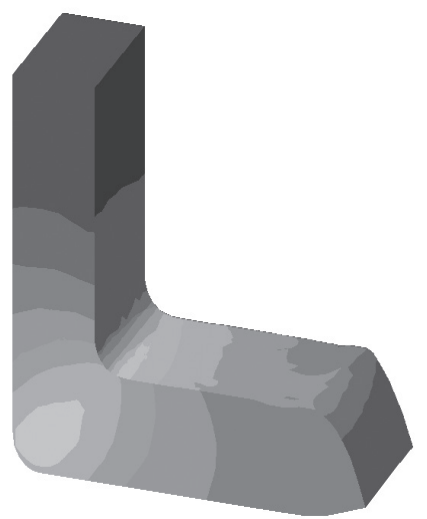

Fig. 3. Temperature distribution $\left({ }^{\circ} \mathrm{C}\right)$ in samples pushed by the channel with section: square $(a)$; circular (b); rectangular longitudinal (c); and rectangular transverse (d) 
a)

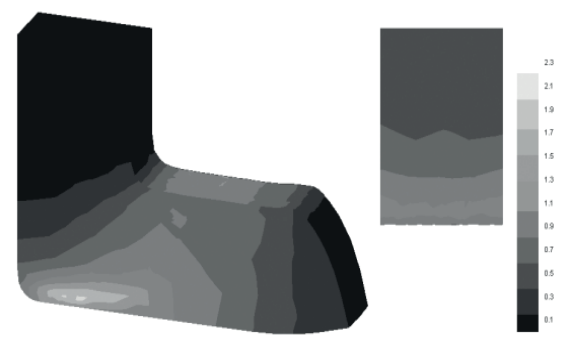

c)

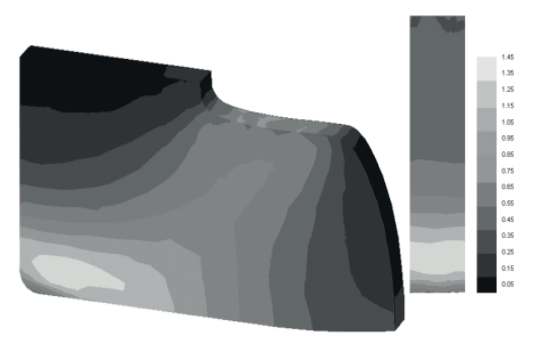

b)

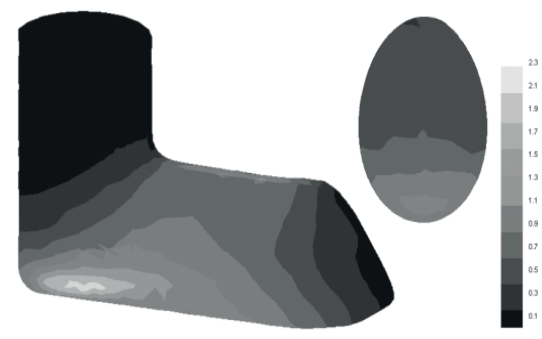

d)

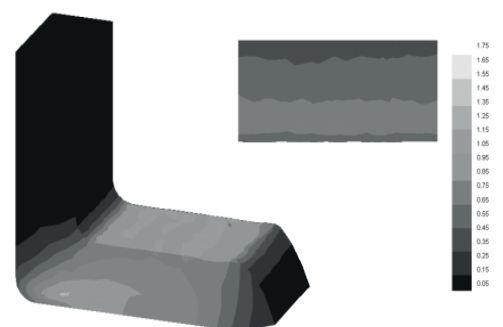

Fig. 4. Effective strain distribution in samples pushed by the channel with section: square (a); circular (b); rectangular longitudinal (c); and rectangular transverse (d)

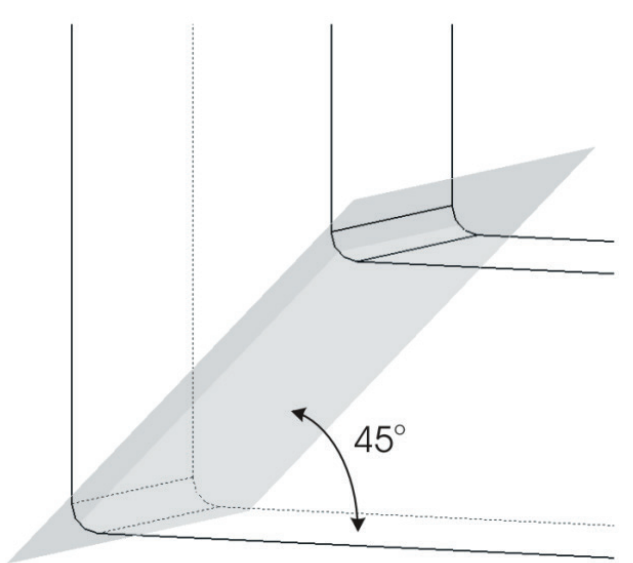

Fig. 5. Position of plane, whose maps of strain distribution were made for individual variants of pushing process 
In order to test the influence of the channel cross-sectional shape on the homogeneity of the strain, a plot of the local effective strain distribution for 17 measuring points was prepared (Fig. 6a). The points were situated in the plane of symmetry of the sample in a straight line spaced $15 \mathrm{~mm}$ from the end of the upper radius of the channel (Fig. 6b). The choice of location of the measurement points is characteristic - they run in a predetermined area after passing through the strain zone, which is located between the upper and lower radii of the die channel. The most homogenous strain is obtained for the samples with square and transverse rectangular cross-sections. The arithmetic means of the effective strain values for these samples at the analyzed points are (respectively) 0.96 and 1.10. In the sample pressed through the circular channel, the mean value is 1.11 ; however, there is a large spread between the extreme values of the strain - especially at the upper part and at the bottom of the channel. The lowest value of the arithmetic mean was obtained for the sample with the longitudinal rectangular section - it was 0.7.

a)

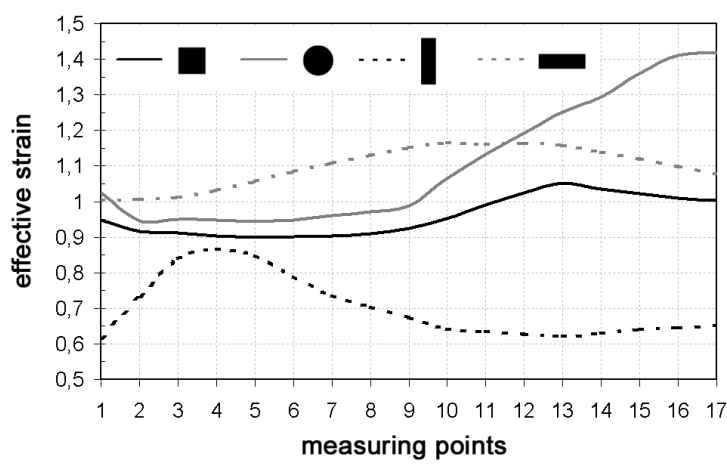

b)

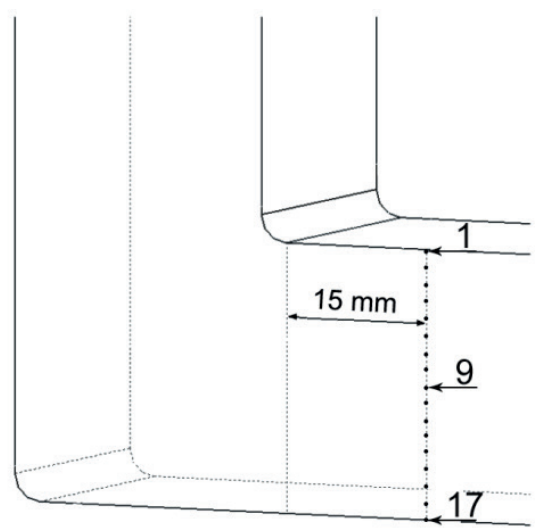

Fig. 6. Channel cross-section influence on the local effective strain distribution (a); and localization of the measuring points (1-17) on symmetry plane of samples (b) in pushing process 
The influence of the cross-sectional shape of the die channel on the value and waveform of the force during application of the method of equal-channel angular pressing is demonstrated in Figure $7 \mathrm{a}$. The pressing force increases at the beginning of the process to a value of $15.30 \%$ of the rolling reduction, and then it stabilizes, with its course close to a horizontal line to the abscissa. The slight decrease in force values in this section is due to the non-uniformity of the metal flow - its retardation against the walls of the channel contributes to the formation of the so-called dead-metal zone. The consequence is a smaller surface of friction and decreased force. To find the average force necessary for the pressing of the material, the arithmetic mean was calculated for the 15 values of force for the rolling reduction of 30 to $100 \%$, at every $5 \%$ (Fig. $7 \mathrm{~b}$ ). The smallest force required for the samples to be pressed through is for the channel with the circular crosssection, and it amounts to $59.32 \mathrm{kN}$. This sample has the smallest lateral surface area; thus, a minimum amount of the material is in contact with the tools. The active surface of friction is minimized. The sample with the rectangular cross-section has the largest surface area. The force necessary for the material to be pressed through a longitudinal rectangular channel is maximal, and it amounts to $71.47 \mathrm{kN}$. It would seem that a similar value should be obtained for the sample shearing in the transverse rectangular channel $(61.66 \mathrm{kN})$, but this force is smaller than for the sample being pressed through the square channel $(62.77 \mathrm{kN})$ and larger than for the circular cross-sectional sample shearing. The reasons lie behind different lateral surfaces $S_{i}$, where the metal is in contact with the dies in the stabilized process (i.e., for the values of rolling reduction from $15-30 \%$ to $100 \%$ ). The location and surface area of this plane for the samples with square and rectangular cross-sections are presented in Table 2 (taking into account the values of the channel radii). The authors speculate that this is this plane that affects the mean value of the force of the stabilized process.

a)

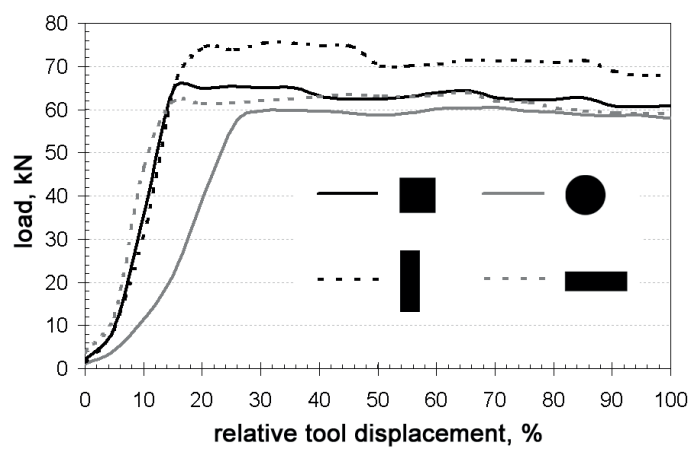

b)

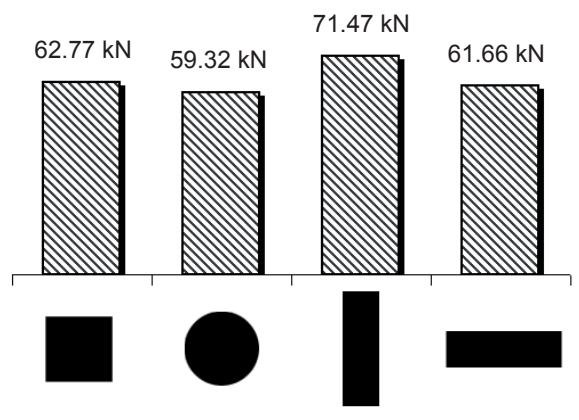

Fig. 7. Channel cross-section influence on process course (a) and averaged maximal load value (b) in pushing process 
Table 2. Position and lateral area $S_{i}$ for channels with square and rectangular cross-sections

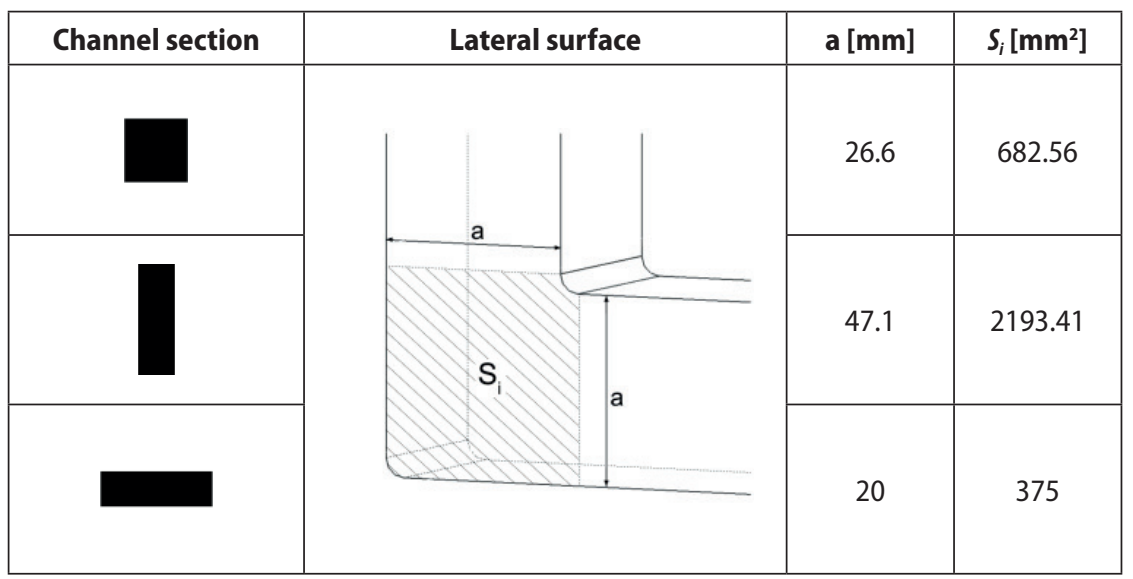

\section{Summary and conclusions}

The performed analysis demonstrates that the cross-sectional shape of the channel used for angular pressing affects the value and homogeneity of the effective strain distribution. A good mechanical processing of the material at a relatively small non-homogeneity of the strain will be obtained for the channels with the square and transverse rectangular cross-sections. Based on the results of numerical calculations, it is concluded that, in addition to the values of the radius, angles, and inclination of the die channel $[3,4]$, an important geometric parameter in the ECAP method is the cross-sectional shape. For the rectangular channel pressing, channel width is far more significant, not its depth.

\section{Acknowledgement}

The study has been carried out with the financial support from the statutory research No. 11.11.110.292 of AGH University of Science and Technology.

\section{References}

[1] Łukaszek-Sołek A., Sińczak J., Bednarek S.: The numerical modelling of strain distribution during ECAP process. Engineering and Education, Białka Tatrzańska, 14-16.11.2007, Eds. Paweł Kurtyka [et al.]: Problems of modern techniques in engineering and education. Pedagogical University of Cracow, Institute of Technology, 117-123

[2] Segal V.I., Reznikov V.M., Drobyshevskiy A.Ye., Kopylov V.I.: Plasticheskaya obrabotka metallov prostym sdvigom. Metally, 1 (1981), 115-123 [Сегал В.И., Резников В.М., Дробышевский А.Е., Копылов В.И.: Пластическая обработка металлов простым сдвигом. Металлы, 1 (1981), 115-123] 
[3] Iwahashi Y., Wang J., Horita Z., Nemoto M., Langdon T.G.: Principle of Equal-Channel Angular Pressing for the Processing of Ultra-Fine Grained Materials. Scripta Materialia, 35, 2 (1996), 143-146

[4] Goforth R.E., Hartwig K.T., Cornwell L.R.: Severe Plastic Deformation of Materials by Equal Channel Angular Extrusion (ECAE). In: Lowe T.C. and Valiev R.Z. (eds.): Investigations and Applications of Severe Plastic Deformation. NATO Science Series, vol. 80, Series 3: High Technology, Springer Netherlands 2000, 3-12

[5] Petrov P., Petrov M., Vasileva E., Dubinchin A.: Research on Friction during Hot Deformation of Al-Alloys at High Strain Rate. http://esaform2008.insa-lyon.fr/proceedings/MS18/p_Pe_255.pdf [28.06.2008] 